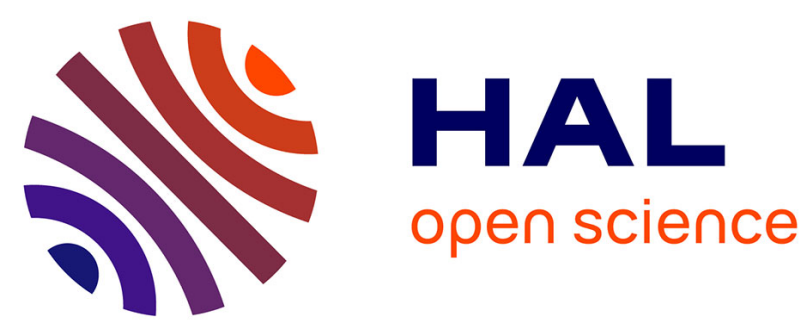

\title{
Integrating crop bioterrorism hazards into pest risk assessment tools
}

J.D. Mumford, A.W. Leach, J. Holt, Frederic Suffert, Ivan Sache, Bénédicte Moignot, Alexander Hamilton

\section{To cite this version:}

J.D. Mumford, A.W. Leach, J. Holt, Frederic Suffert, Ivan Sache, et al.. Integrating crop bioterrorism hazards into pest risk assessment tools. Practical tools for plant and food biosecurity, , 384 p., 2017, Plant Pathology in the 21st Century, 10.1007/978-3-319-46897-6 . hal-02787698

\section{HAL Id: hal-02787698 \\ https://hal.inrae.fr/hal-02787698}

Submitted on 5 Jun 2020

HAL is a multi-disciplinary open access archive for the deposit and dissemination of scientific research documents, whether they are published or not. The documents may come from teaching and research institutions in France or abroad, or from public or private research centers.
L'archive ouverte pluridisciplinaire HAL, est destinée au dépôt et à la diffusion de documents scientifiques de niveau recherche, publiés ou non, émanant des établissements d'enseignement et de recherche français ou étrangers, des laboratoires publics ou privés. 


\section{Chapter 6}

Integrating Crop Bioterrorism Hazards into Pest Risk Assessment Tools

John D. Mumford, Adrian W. Leach, Johnson Holt, Frédéric Suffert, Ivan Sache, Benedicte Moignot, and R. Alexander Hamilton

Abstract Risks from intentional releases of organisms to agriculture, the food chain or the environment must be assessed to ensure proportionate planning just as ccidental releases from trade or natural spread must be predicted so that mant as ment can be organised. Pest risk assessment methods are well established for related introductions and it is efficient to build on these and adapt avaloble risk assessment components from agricultural and onvirone Some additional risk Son intion, capacity and intended impact of a perpetrator should be included, and some key elements of trade related assessments, such as the volume of trade, may be irrelevant for intentional targeted releases. Risk levels from the various causes and impacts should be comparable to allow authorities to direct responses appropriately. Prevent be actions, for both intentional and unintentional introductions, are particularly impor-

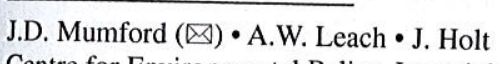

Silwood Park Cand

e-mail: j.mumford@impriat

imperial.ac.uk; j.holt@imperial.ac.uk

F. Suffert

78850 Ther, INRA, AgroParisTech, Université Paris-Saclay,

78850 Thiverval-Grignon, France

Cropbiosecurity and Agroterrorism Watch, Paris, France

e-mail: frederic.suffert@inra.fr; cropsafexpertise@yahoo.fr

I. Sache

INRA, UMR1290 BIOGER, Campus INRA-AgroParisTech,

-mail: ivanerval-Grignon, France

B. Moignot

Anses, Laboratoire de la santé des végétaux, Unité Evaluation des Risques Biologiques, e-mail: benedixéras, 49045 Angers Cédex, France

R.

R.A. Hamilton

United Nations Interregional Crime and Justice Research Institute (UNICRI)

S-male Maestri del Lavoro, 10, 10127 Turin, Italy

e-mail: hamilton@unicri.it

- Springer International Publishing AG 2017

M.L. Gullino et al. (eds.), Practical Tools for Plant and Food Biosecurity, Plan

Pathology in the 21st Century 8, DOI 10.1007/978-3-319-46897-6_6 
tant. For intentional release this puts emphasis on motivation, capacity and sources. A scenario based approach to assessing intentional release risks is taken to develop a pest risk assessment tool that can cover the range of levels of potential activity. A risk assessment framework is illustrated and a range of example scenarios is
described.

Keywords Risk assessment • Intentional release • Plant health • Agroterrorism • Bioterrorism $\bullet$ Biocrime $\bullet$ Biowarfare $\bullet$ Pest risk analysis $\bullet$ Risk model

\subsection{Introduction}

Traditionally, crop biosecurity efforts have focused on preventing and responding to the natural or unintentional introduction, establishment and spread of pests or pathogens. Government agencies and industries take steps to limit these accidental measures, public and private standards in trade, official rules on risk mitigation and capacity. This organisms, and control planning Pest Risk Analysis (PRA), which have burity has driven standardised approaches to identify, assess, manage and commune been developed to enable risk managers to EPPO 2011). Some Eurs of this kind (IPPC 2004, 2007; have developed (Baker et al. 2014. (Moignot and Reynaud 2013), in) and methodology for prioritizing plant pests EU plant health regulation (now in order to comply with the requirements of the new recent years there biological agents again growing concern about the possible deliberate misuse of gainst agriculture and the food supply with a view to causing Commission 2007).

Referred to broadly as agroterrorism, ${ }^{1}$ this possibility has, in turn, motivated calls at the national and international level to ensure that public and private responses to possible threats from harmful organisms include both unintended and intentional releases. This requires a reassessment and revision of standard approaches to PRA to explicitly account for the motives and capabilities of potential attackers who might choose to deliberately misuse biological agents in pursuit of particular political or ideological goals. As a consequence, security becomes yet another consideration, in addition to biosecurity, that should be incorporated within a Pest Risk

\footnotetext{
'The term 'agroterrorism' is commonly used to refer to the 'deliberate misuse of biological agents ter, we also include 'biocrime' and 'biowat (that, a subset of 'bioterrorism'). However, in this chapeach of these 'agro-risks' repres 'biowarfare' under this general definition. Our rationale is that of risk in agriculture, which focus on mote of 'deliberate misuse', distinct from traditional views sess some specific char or these risks poslegal terms (see Chap. 7) and we con bioterrorism', 'biocrime', and 'biowarfare' are defined in
} 